\title{
Radiation therapy and vaccination against tumor-specific EGFRvIll effectively clears tumors in a murine model of head and neck squamous cell carcinoma
}

\author{
Lauren Uhde ${ }^{1,2^{*}}$, Shelly Bambina ${ }^{1}$, Alejandro Alice ${ }^{1}$, Peter Lauer ${ }^{3}$, Marka Crittenden ${ }^{1,4,5}$, Keith S Bahjat ${ }^{1,4,6}$, \\ Michael Gough ${ }^{1,4}$
}

From 30th Annual Meeting and Associated Programs of the Society for Immunotherapy of Cancer (SITC 2015) National Harbor, MD, USA. 4-8 November 2015

EGFRvIII is a constitutively active and tumor-specific deletional mutant of EGFR found in multiple tumor types including glioblastoma multiforme, and has been reported in head and neck squamous cell carcinomas (HNSCC). The deletion of EGFR exons 2-7 results in a novel glycine at the junction and yields a tumor-specific antigen with demonstrated immunogenicity in mice and humans. Using a live-attenuated Listeria monocytogenesbased vaccine expressing a 21-AA neo-peptide from EGFRvIII (LmEGFRvIII), we demonstrated that prophylactic vaccination protects against subsequent challenge with an EGFRvIII-expressing squamous cell carcinoma (SCCVII-EGFRvIII). Similarly, therapeutic vaccination three days post-implantation prevented outgrowth of EGFRvIII-expressing tumors but not parental EGFRvIIInegative tumors. Conversely, we found that LmEGFRvIII vaccination was insufficient to clear large established SCCVII-EGFRvIII tumors despite eliciting large numbers of polyfunctional EGFRvIII-specific CD8+ T cells. We hypothesized that localized inflammation elicited by radiation therapy could recruit EGFRvIII-specific CD8+ $\mathrm{T}$ cells into the tumor. We demonstrated that while neither LmEGFRvIII vaccination nor radiation therapy alone were able to control the EGFRvIII-expressing tumors, the combination of LmEGFRvIII and radiation therapy led to tumor regression and durable cures. We are currently exploring the potential mechanisms for their synergy including the role of $\mathrm{T}$ cell recruitment, survival and epitope spreading.

Earle A. Chiles Research Institute, Portland, OR, USA

Full list of author information is available at the end of the article

\section{Authors' details}

${ }^{1}$ Earle A. Chiles Research Institute, Portland, OR, USA. ${ }^{2}$ Molecular Microbiology and Immunology, OHSU, Portland, OR, USA. ${ }^{3}$ Aduro Biotech, Berkeley, CA, USA. ${ }^{4}$ Providence Cancer Center; The Oregon Clinic, Portland, OR, USA. ${ }^{5}$ The Oregon Clinic, Portland, OR, USA. ${ }^{6}$ Robert W. Franz Cancer Research Center, Portland, OR, USA.

Published: 4 November 2015

\section{doi:10.1186/2051-1426-3-S2-P78}

Cite this article as: Uhde et al:: Radiation therapy and vaccination against tumor-specific EGFRvIll effectively clears tumors in a murine model of head and neck squamous cell carcinoma. Journal for ImmunoTherapy of Cancer 2015 3(Suppl 2):P78.

\section{Submit your next manuscript to BioMed Central and take full advantage of: \\ - Convenient online submission \\ - Thorough peer review \\ - No space constraints or color figure charges \\ - Immediate publication on acceptance \\ - Inclusion in PubMed, CAS, Scopus and Google Scholar \\ - Research which is freely available for redistribution \\ Submit your manuscript at www.biomedcentral.com/submit}

